\title{
PENDIDIKAN AKHLAK ANAK DI ERA DIGITAL
}

\author{
Suhartono, Nur Rahma Yulieta \\ Sekolah Tinggi Ilmu Tarbiyah Madani Yogyakarta
}

\begin{abstract}
Abstraks
Digitalisasi membawa dampak pada seluruh aspek kehidupan manusia, perubahan pola pikir dan gaya hidup tidak dapat dihindarkan. Salah satu masalah yang sangat menghawatirkan adalah munculnya berbagai macam media sosial yang dapat merusak akhlak. Pendidikan akhlak menjadi sangat penting dan harus mendapatkan prioritas utama untuk dilakukan oleh orang tua dirumah maupun pendidik di sekolah. Pendidikan akhlak dengan metode yang tepat menjadi kunci utama agar anak mampu mengendalikan diri dalam menggunakan media digital dan bisa memanfaatkan kecanggihan teknologi dan komunikasi untuk hal-hal yang berguna bagi dirinya. Adapun metode dalam pendidikan akhlak yang dapat diterapkan di era digital sekarang ini diantaranya adalah; metode keteladanan, pembiasaan, nasehat, perhatian, humukan dan pengawasan.
\end{abstract}

Kata kunci : Pendidikan, Akhlak, Era digital

Digitalization has an impact on all aspects of human life, changes in mindset and lifestyle cannot be avoided. One of the most worrying problems is the emergence of various types of social media that can damage morals. Moral education is very important and must get top priority for parents at home and educators at school. Moral education with the right method is the main key so that children are able to control themselves in using digital media and can utilize the sophistication of technology and communication for things that are useful for themselves. The methods in moral education that can be 
applied in the digital era today include; exemplary, habituation, advice, attention, humukan and supervision methods.

Keywords: Education, Morals, Digital Era

\section{A. Pendahuluan}

Kecanggihan ilmu pengetahuan dan teknologi pada saat sekarang ini telah membuat dunia seakan tanpa batas, berbagai macam aktivitas komunikasi secara maya ke seluruh penjuru dunia dalam waktu singkat serta majunya teknologi dan komunikasi memicu berbagai perubahan kehidupan manusia. Hal ini ditandai dengan semakin sentralnya peran teknologi cyber dalam segala bidang kehidupan.

Digitalisasi membawa dampak pada seluruh aspek kehidupan manusia, pola piker yang instan, praktis dan tidak memperhatikan sisi proses, serta perubahan gaya hidup tidak dapat dihindarkan. Salah satu masalah yang sangat menghawatirkan adalah munculnya media sosial yang dapat merusak akhlak. Anak-anak yang lahir dimasa ini sekarang langsung dihadapkan pada "dua dunia" yaitu dunia nyata dan dunia maya, orang tua memegang peranan yang sangat penting untuk menciptakan kondisi lingkungan agar anak lebih siap dalam menghadapi berbagai tantangan di era digital. Oleh karena itu, pendidikan akhlak menjadi sangat penting, agar anak memiliki bekal yang cukup untuk menjalani kehidupan selanjutnya. 
Kunci kebahagiaan seseorang ada pada perangai dan karakternya ,ketika seseorang senantiasa membiasakan diri dengan karakter baik, maka hal ini menjadi tanda kebaikannya. Mengenai hal ini Ibnu Qayyim menjelaskan bahwa kebahagian dan kesengsaraan seseorang ada pada perangai dan karakternya, dan tiada yang bisa menggapai kebaikan di dunia dan di akhirat kecuali dengan perangai dan karakter yang baik. ${ }^{1}$

Pendidikan akhlak dengan metode yang tepat menjadi kunci utama agar anak mampu mengendalikan diri dalam menggunakan media digital dan bisa memanfaatkan kecanggihan teknologi dan komunikasi untuk hal-hal yang berguna bagi dirinya, namun anak tetap terhindar dari pengaruh buruk yang ditimbulkannya. Sehingga anak dapat menggapai kebahagiaan, kemuliaan serta keselamatan hidup di dunia dan akhirat.

\section{B. Pendidikan Akhlak}

Dalam Kamus Besar Bahasa Indonesia dijelaskan bahwa pendidikan adalah proses pengubahan sikap dan tata laku seseorang atau kelompok orang dalam usaha mendewasakan manusia melalui upaya pengajaran dan pelatihan ${ }^{2}$

Dalam konteks Islam istilah pendidikan telah dikenal dengan istilah at-tarbiyah yang berasal dari kata -Ñ̀̀í - îNÈí É

\footnotetext{
1 Ibnu Qayyim, Madaarijus Saalikiin wa Baina Manaazil Iyyaaka Na'budu WaIyyaaka Nasta'iin, (Beirut : Dar Ehia Al-Thourath Al-Arabi, 1999), Vol.2, hlm. 294

2 Departemen Pendidikan Nasional, Kamus Besar Bahasa Indonesia, (Jakarta: Gramedia Pustaka Utama, 2013), h. 326.
} 
ÊÑÈí yang berarti memelihara, mendidik, mengasuh. Menurut Ibnu Abdillah Muhammad bin Ahmad alAnshari al-Qurthubi mengartikan bahwa rabb adalah pemilik, maha memperbaiki, maha mengatur, maha menambah, maha menunaikan. Sedangkan menurut al-Jauhari adalah memberi makan, memelihara, mengasuh. ${ }^{3}$ Dalam al-Qur'an kata "rabba" ini digunakan untuk Tuhan, karena Tuhan sifatnya mendidik, mengasuh, memelihara dan pencipta.

Tarbiyah menurut Ibnu Qoyyim al- Jauziyah, mencakup tarbiyah qalb (pendidikan hati) dan tarbiyah badan secara sekaligus. Dan beliau menjelaskan kaifiyah (cara) mentarbiyah hati dan badan tersebut. Beliau berkata " Antara hati dan badan sama-sama membutuhkan kepada tarbiyah. Keduanya harus ditumbuhkembangkan dan ditambah gizinya sehingga mampu tumbuh dengan sempurna dan lebih baik dari sebelumnya. ${ }^{4}$

Dari uraian pengertian tentang pendidikan tersebut, dapat dipahami bahwa pendidikan merupakan upaya membimbing, membina dan mengarahkan agar anak mendapatkan kebaikan. Hal ini sangat penting bagi orang tua maupun pendidik di era digital seperti sekarang ini supaya anak mampu memanfaatkan teknologi dengan benar dan terhindar dari kerusakan yang diakibatkan lepas kontrol dalam menggunakan teknologi informasi.

\footnotetext{
${ }^{3}$ Yatimin Abdullah, Studi Akhlak dalam Perspektif al-Qur'an, hlm. 22.

${ }^{4}$ Ibnu Qayim Al-Jauziyah, Ighatsanu Lahfan min Mushahidis Syetan, (Kairo: tp, 1999), Juz I, hlm. 46.
} 
Adapun akhlak menurut Hamzah Ya'qub berasal dari bahasa Arab, jamak dari kata "khuluqun", artinya tindakan. Kata "khuluqun" sepadan dengan kata "khalqun", artinya kejadian dan kata "khaliqun". Artinya pencipta dan kata "makhluqun", artinya yang diciptakan. Dengan demikian, rumusan terminologis dari akhlak merupakan hubungan erat antara Khaliq dengan makhluq serta antara makhluq dengan makhluq. ${ }^{5}$

Menurut Ibnu Maskawaih akhlak adalah sifat yang tertanam dalam jiwa yang mendorongnya untuk melakukan perbuatan tanpa memerlukan pemikiran dan pertimbangan. 6

Al-Mawardi mengungkapkan: "Seseorang dikatakan berakhlak mulia jika budi peketinya halus, berwaatak lembut, wajahnya ceria, tidak suka menghardik dan selalu bertutur kata yang baik. 7

Syaikh Ibnu Sa'di mengatakan : "Akhlak mulia adalah akhlak yang utama dan agung. Ia dibangun diatas kesabaran, kelembutan dan kecenderungan pada perangai yang terpuji. Akhlak inipun melahirkan sikap mudah memaafkan, mampu bersikap toleran terhadap orang lain dan senang berbagi manfaat bagi sesama insan. Akhlak terpuji terwujud pula dengan kesabaran dalam menghadapi berbagai kejahatan orang lain,

\footnotetext{
${ }^{5}$ Beni Ahmad Saebani, Abdul Hamid,Ilmu Akhlak, (Bandung: Pustaka Setia, 2010), hlm. 14 .

${ }^{6}$ Ibid...

7 Abul Hasan al-Mawardi, Adaabud Dunyaa wad diin, tahqiq Muhamad Karim Rajih,(Daar Iqra' cet ke- 4, 1985) hlm. 243
} 
memaafkan kekeliruan sesamanya dan membalas keburukan mereka dengan kebaikan. ${ }^{8}$

Dari beberapa pengertian di atas, dapat diambil pemahaman bahwa pendidikan akhlak adalah usaha sadar, teratur, dan sistematis di dalam memberikan bimbingan dan pembinaan oleh orang tua dirumah atau pendidik disekolah kepada anak menuju terbentuknya kebiasaan dan perilaku mulia serta kepribadian yang kuat.

Kecenderungan manusia dalam melakukan akhlak baik atau buruk, merupakan bentuk dari proses, proses inilah yang sebenarnya sangat berperan dalam membentuk perilaku akhir dari kecenderungan manusia. Proses ini yang kemudian dijadikan oleh para ahli pendidikan untuk mengonsep agar manusia tetap bertahan dalam kebaikan, yaitu melalui pendidikan. Inilah letak urgensi pendidikan akhlak tersebut, terutama anak-anak, sebab untuk mewujudkan generasi yang berakhlak mulia di era digital seperti sekarang ini, cara yang paling efektif adalah dengan pendidikan kepada anak sejak dini.

Pendidikan akhlak adalah salah satu pendidikan yang wajib diberikan kepada anak sedini mungkin. Hal ini dikarenakan anak masih suci dan bersih dan belum terkontaminasi dengan berbagai peragai buruk. Oleh karena itu, sebagai orang tua perlu mengajarkan dan mencontohkan perbuatan-perbuatan yang

8 Abdurrahman As-Sa'di , Ar-riyadh an-Nadhiroh.. hlm. 68 
mulia yang sesuai dengan ajaran al-quran dan hadist nabi Muhammad Shalallahu'alaihiwasalam.

Menurut Ahmad amin, ada beberapa perkara yang menguatkan pendidikan akhlak dan meninggikannya, yaitu:

1. Meluaskan lingkungan fikiran, karena fikiran yang sempit merupakan sumber beberapa keburukan dan akal yang kacau balau tidak dapat membuahkan akhlak yang tinggi.

2. Berkawan dengan orang yang terpilih, hal ini dikarenakan manusia itu suka mencontoh.

3. Membaca dan menyelidiki perjalanan para pahlawan dan yang berfikiran luar biasa.

4. Yang lebih penting memberi dorongan kepada pendidikan akhlah ialah supaya orang mewajibkan dirinya melakukan perbuatan baik bagi umum (lebih mengutamakan kepentingan umum).

Berusaha melakukan kebiasaan dengan perbuatan yang baik. ${ }^{9}$ Tujuan pendidikan akhlak diberikan kepada anak supaya dapat membersihkan diri dari perbuatan dosa dan maksiat. Karena sebagai manusia yang memiliki jasmani dan rohani, maka jasmani dibersihkan secara lahiriah melalui fikih sedangkan rohani dibersihkan secara bathiniah melalui akhlak. Orang yang memiliki batin atau hati yang bersih akan melahirkan perbuatan yang terpuji sehingga dengan perbuatan terpuji maka akan

9 Ahmad amin, Etika (Ilmu akhlak),(Jakarta: Bulan Bintang,1975),hlm.63 - 66

42 AT-TUROTS: Jurnal Pendidikan Islam 
melahirkan masyarakat yang saling menghargai dan bahagia dunia dan akhirat.

Akhlak diajarkan kepada anak juga betujuan agar anak dapat mengetahui hal-hal yang baik dan dianjurkan untuk menlaksanakannya dalam kehidupan sehari-hari dan mengetahui perbuatan yang tercela serta bahayanya agar dihindari supaya tidak merugikan terhadap kehidupan anak. Dengan demikian anak akan mampu memilah hal yang mana yang boleh dilakukan dan yang man yang harus ditinggalkan atau dijauhi. Secara singkat tujuan pendidikan akhlak adalah mendidik budi pekerti dan pembentukan jiwa anak melalui pelajaran, pembinaan dan bimbingan akhlak baik yang dilakukan di sekolah maupun di lingkungan keluarga.

Pendidikan akhlak merupakan pendidikan nilai yang pertama didapat anak dari keluarganya. Hasil penelitian Rohner menunjukkan bahwa pengalaman masa kecil seseorang sangat mempengaruhi perkembangan kepribadiannya. Pola asuh orang tua baik yang menerima atau yang menolak anaknya, akan mempengaruhi perkembangan emosi, perilaku, social-kognitif, dan kesehatan fungsi psikologisnya hingga dewasa.

\section{Era Digital}

1. Pengertian Era Digital

Era digital merupakan suatu masa dimana sebaian besar manusia pada masa tersebut menggunakan sistem digital 
dalam kehidupan sehari-hari. Sisem digital ini lebih canggih dibandingkan dengan sistem sebelumnya yaitu sistem analog. Sistem analog menghasilkan sinyal tiruan yang didapat dari alam, sehingga sering terjadi degradasi sinyal yang mengakibatkan sinyal kurang jelas. Sebaliknya sistem digital dapat menghilangkan faktort penggangu dengan mentransmisi sinyal asli menjadi bits dan membuat sampel gelombang suara mengaturnya berdasarkan kecepatan tertentu sehingga sinyal lebih jernih dan tidak mengalami sinyal tunda.

Media pada era digital memiliki karakteristik dapat dimanipulasi dan bersifat jaringan. Kemampuan media era digital ini lebih memudahkan masyarakat dalam menerima informasi. Semakin canggihnya teknologi digital masa kini membuat perubahan besar terhadap dunia, lahirnya berbagai macam teknologi digital yang semakin maju telah banyak bermunculan.

Berbagai kalangan telah dimudahkan dalam mengakses suatu informasi melalui banyak cara, serta dapat menikmati fasilitas dari teknologi digital dengan bebas dan terkendali. Era digital juga membuat ranah privasi orang seolah-olah hilang. Data pribadi yang terekam di dalam otak komputer membuat penghuni internet mudah dilacak. Era digital bukan persoalan siap atau tidak dan bukan pula suatu opsi namun sudah merupakan suatu konsekuensi. Teknologi akan terus berkembang dan bergerak terus tanpa henti yang berjalan 
ditengah-tengah kehidupan manusia. Maka tidak ada pilihan lain selain menguasai dan mengendalikan teknologi dengan baik dan benar agar membaik.

2. Dampak Positif dan Negatif Era Digital

Dalam perkembangan teknologi digital ini terdapat banyak dampak yang dirasakan oleh manusia, baik dampak postif maupun dampak negatifnya. Dampak positif era digital antara lain:

a. Informasi yang dibutuhkan dapat lebih cepat dan lebih mudah dalam mengaksesnya.

b. Tumbuhnya inovasi dalam berbagai bidang yang berorentasi pada teknologi digital yang memudahkan proses dalam pekerjaan.

c. Munculnya media massa berbasis digital, khususnya media elektronik sebagai sumber pengetahuan dan informasi masyarakat.

d. Meningkatnya kualitas sumber daya manusia melalui pengembangan dan pemanfaatan teknologi informasi dan komunikasi.

e. Munculnya berbagai sumber belajar seperti perpustakaan online, media pembelajaran online, diskusi online yang dapat meningkatkan kualitas pendidikan.

f. Munculnya e-bisnis seperti toko online yang menyediakan berbagai barang kebutuhan dan memudahkan mendapatkannya. 
Adapun dampak negatif era digital yang harus diantisapasi, antara lain:

a. Pelanggaran Hak Kekayaan Intelektual (HKI) karena akses data yang mudah dan menyebabkan orang melakukan kecurangan.

b. Pikiran instan dimana anak-anak seperti terlatih untuk berpikir pendek dan kurang konsentrasi.

c. Penyalahgunaan pengetahuan untuk melakukan tindak pidana seperti menerobos sistem perbankan.

d. Menurunnya moralitas yan disebabkan mudahnya mengakses situs pornorafi dan pornoaksi.

e. Munculnya sikap individualis anti sosial.

\section{Metode Pendidikan Akhlak Di Era Digital}

Metode pendidikan akhlak yang dapat dilaksanakan oleh orang tua dirumah maupun para pendidik disekolah diantaranya adalah sebagai berikut:

1. Metode Keteladanan (Uswatun Hasanah)

Anak-anak memiliki kecenderungan atau sifat peniru yang sangat besar,maka metode uswatun hasanah "contoh teladan yang baik" dari orang-orang yang dekat dengan anak itu yang paling tepat. Dalam hal ini, orang yang paling dekat kepada anak adalah orang tuanya dirumah , karena itu contoh teladan dari orang tuanya sangat berpengaruh pada pembentukan mental dan akhlak anak-anak. Keteladanan 
dalam pendidikan adalah metode yang paling meyakinkan keberhasilannya dalam mempersiapkan dan membentuk anak di dalam moral, spiritual dan sosial. Selanjutnya pendidik di sekolah adalah contoh terbaik dalam pandangan anak yang akan ditirunya dalam tindak-tanduknya dan tata santunnya, disadari ataupun tidak, bahkan tercetak dalam jiwa dan perasaan suatu gambaran pendidik tersebut, baik dalam ucapan ataupun dalam perbuatan, baik material atau spiritual, diketahui atau tidak diketahui. ${ }^{10}$

Tanpa memberikan teladan yang baik, pendidikan terhadap anak-anak tidak akan berhasil, dan nasihat tidakakan membekas, segala bentuk ucapan maupun tindakan orang tua dan pendidik akan ditiru oleh anak. Secara lambat laun seorang anak itu akan mengetahui dengan sendirinya bahwa perbuatan yang ia lakukan adalah merupakan kewajiban yang harus dilaksanakan tidak semata-mata karena mengikuti perilaku orang tua dan pendidik.

Orang tua harus memberikan contoh kepada anak dalam pemanfaatan teknologi informasi seperti internet, gadget, Hp dan yang lainnya. Alat-alat digunakan untuk hal-hal yang bermanfaat, selalu memperhatikan waktu dan tempat yang tepat.

10 Abdullah Nashih Ulwan, Pedoman Pendidikan Anak dalam Islam, Juz II, terj., Drs.Saifullah Kamalie, Lc, Drs. Hery Noer Ali, Semarang, Asy Syifa', 1981, h. 2. 
2. Metode Pembiasaan

Sejak kecil anak harus dibiasakan untuk melakukan kegiatan-kegiatan yang baik, dilatih untuk bertingkah laku yang baik, diajari sopan santun dan sebagai-nya. Mendidik, melatih, dan membimbing anak secara perlahan adalah hal yang wajib diterapkan pada anak agar dia dapat meraih sifat dan ketrampilan dengan baik, agar keyakinan dan akhlaknya tertanam dengan kokoh. Akhlak dan prinsip-prinsip keyakinan, termasuk di dalamnya ketrampilan anggota tubuh, membutuhkan adanya proses bertahap untuk dapat diraih dan harus dilakukan secara kebiasaan atau berulang-ulang sehingga tercapai dan dikuasai dengan baik, serta dapat dilaksanakan dengan mudah dan ringan, tanpa bersusah payah dan menemukan kesulitan. ${ }^{11}$

Orang tua di rumah ataupun pendidik di sekolah harus selalu mengajari, melatih dan membiasakan anak untuk bertutur kata yang sopan, ramah, lembut dan santun, karena seorang anak mengikuti ucapan yang dilatihnya. Tingkah laku seorang anak tergantung kepada siapa yang mengajarinya kalau anak tersebut dilatih uacapan ataupun perbuatan baik maka anak juga menjadi baik dan begitu pula sebaliknya.

Dalam hal pemanfaatan teknologi informasi anak juga perlu dibiasakan dengan pembatasan waktu sehingga tidak

11 Muhammad Husain, Agar Anak Mandiri, terj., Nashirul Haq, (Bandung, Irsyad Baitus Salam, 2007), hlm. 11. 
mengalami ketergantungan atau bahkan kecanduan internet, games dan yang lainnya.

3. Metode Nasihat (Mau'izhah al-Hasanah )

Nasihat dapat membukakan mata anak-anak pada hakikat sesuatu, mendorongnya menuju situasi luhur, menghiasi dengan akhlak yang mulia dan membekalinya dengan prinsip-prinsip Islam. Metode al-Qur'an dalam menyerukan dakwaan adalah bermacam-macam. Nasihat yang tulus membekas dan berpengaruh, jika memasuki jiwa yang bening, hati terbuka, akal yang bijak, maka nasihat tersebut akan mendapat tanggapan secepatnya dan meninggalkan bekas yang dalam. ${ }^{12}$

Nasihat dapat berupa anjuran yaitu saran atau ajakan untuk berbuat atau melakukan sesuatu yang baik dan berguna, dengan adanya anjuran menanamkan kedislipinan, melaksanakan kewajiban perintah agama pada anak, sehingga akhirnya menjalankan segala sesuatu dengan disiplin yang nantinya akan membentuk suatu kepribadian yang mulia. Seperti dalam sabda Rasulullah bahwa seorang anak ketika masih umur 7 tahun atau mungkin di bawahnya harus di ajak untuk melaksanakan shalat lima waktu. Anak-anak hendaklah diajak untuk mengerjakan shalat. Sehingga terbentuk manusia yang senantiasa kontak dengan penciptanya. Imam al-Ghazali

12 Abdullah Nashih Ulwan, Pedoman Pendidikan Anak dalam Islam, Juz II, terj., Drs.Saifullah Kamalie, Lc, Drs. Hery Noer Ali, Semarang, Asy Syifa', 1981, hlm. 68 
menjelaskan bahwa seorang anak yang telah mencapai usia tamyiz, maka hendaklah tidak dibiarkan meninggalkan thaharah dan shalat. Juga mulai diperintahkan berpuasa beberapa hari di bulan Ramadhan. ${ }^{13}$

Nasihat juga dapat berupa larangan yang mana merupakan suatu keharusan untuk tidak melakukan perbuatan yang bisa merugikan diri sendiri ataupun orang lain. Usaha ini merupakan tindakan tegas untuk menghentikan perbuatanperbuatan yang sangat jelas kesalahannya. Larangan ini merupakan suatu perbuatan yang tidak pantas untuk dilakukan seperti mencuri, berkelahi dengan temannya, dan lain sebagainya. Perbuatan seperti ini harus dilarang sejak anak masih usia dini, agar ketika sudah dewasa nanti melakukan perbuatan yang dilarang oleh agama merupakan suatu pantangan bagi dirinya. Strategi ini bertujuan untuk membentuk kedislipinan atau perbuata baik bagi anak.

4. Metode Perhatian

Metode pendidikan dengan perhatian adalah mencurahkan, memperhatikan dan senantiasa mengikuti perkembangan anak dalam pembinaan akidah dan akhlak, persiapan spiritual dan sosial selain itu juga bertanya tentang situasi pendidikan jasmani dan daya hasil ilmiahnya. Metode perhatian ini merupakan metode pendidikan yang terkuat dalam pembentukan manusia secara utuh dan dapat

13 Imam al-Ghazali, Ihya 'Ulum ad-Din, terj. Ismail Ya'kub, hlm. 197. 
mendorongnya untuk menunaikan tanggung jawab dan kewajibannya secara sempurna.

5. Metode Hukuman dan Hadiah

Metode hukuman ini merupakan suatu tindakan yang diberikan kepada anak yang secara sadar dan sengaja melakukan suatu kesalahan seperti menyalahgunakan teknologi informasi untuk kejahatan atau kemaksiatan kepada Allah Ta'ala, sehingga dengan adanya hukuman ini anak muncul rasa penyelasan dan tidak melakukan kesalahan untuk yang kedua kalinya. Hukuman ini menghasilkan suatu kedisiplinan pada anak. Pada taraf yang lebih tinggi menginsyafkan anak untuk tidak melakukan suatu perbuatan yang dilarang oleh agama. Berbuat atau tidak berbuat bukan karena takut hukuman, melainkan karena keinsyafan sendiri dan merupakan suatu ketaatan pada Allah dan selalu mengharapkan ridha-Nya.

Pemberian hadiah kepada anak ketika melakukan perbuatan terpuji juga perlu diperhatikan, hadiah tidak selalu berupa materi atau barang, tetapi pemberian hadiah ini juga bisa berupa anggukan dengan wajah yang berseri-seri, acungan jempol dan lain sebagainya, itu semua sudah termasuk hadiah yang mempunyai pengaruh sangat besar kepada peserta didik. Karena, dengan adanya hadiah tersebut bisa menggembirakan anak, menambah kepercayaan pada diri sendiri dan yang lebih penting lagi bisa menjadi lebih semangat lagi dalam belajarnya. 
6. Metode Pengawasan

Metode ini digunakan untuk menjaga agar tidak terjadi hal-hal yang tidak diinginkan. Karena manusia tidaklah sempurna, jadi kemungkinan besar selalu melakukan kesalahan-kesalahan, penyimpangan-penyimpangan ini selalu ada. Maka dari itu, sebelum kesalahan dan penyimpangan itu dilakukan lebih jauh, sebaiknya selalu ada usaha untuk diadakan pengawasan. Apalagi zaman sekarang anak-anak sudah pandai memainkan gadget, dalam hal ini orang tua harus bisa benar-benar mengawasi, karena kalau tidak diawasi nanti anak-anak bisa membuka situs-situs yang terlarang yang semua itu merusak moral dan akhlak anak.

\section{E. Penutup}

Pendidikan akhlak anak perlu adanya perhatian khusus bagi orang tua. Karena baik dan buruknya perilaku anak, bergantung pada pendidikan yang diberikan kepada anak tersebut, jika anak tersebut dididik dengan akhlak yang baik pasti anak tersebut menjadi anak yang baik dan sebaliknya. Pada era digital sekarang ini dengan segala dampak yang terjadi menjadikan tantangan pendidikan akhlak lebih komplek. Metode yang tepat sangat dibutuhkan untuk mendidik akhlak anak, agar anak dimasa depan menjadi manusia yang mempunyai akhlak mulia. 


\section{DAFTAR PUSTAKA}

Abul Hasan al-Mawardi, Adaabud Dunyaa wad diin, tahqiq Muhamad Karim Rajih Daar Iqra' cet ke-4, 1985

Abdurrahman As-Sa'di , Ar-riyadh an-Nadhiroh

Abdullah Nashih Ulwan, Pedoman Pendidikan Anak dalam Islam, Juz II, terj., Saifullah Kamalie, Lc, Drs. Hery Noer Ali, Semarang, Asy Syifa', 1981

Ahmad amin, Etika (Ilmu akhlak),Jakarta: Bulan Bintang,1975

Ahmad DMarimba, Pengantar Filsafat Pendidikan Islam, Bandung: alMa'arif, 1980

Beni Ahmad Saebani, Abdul Hamid,Ilmu Akhlak, Bandung: Pustaka Setia, 2010

Ibnu Qayyim, Madaarijus Saalikiin wa Baina Manaazil Iyyaaka Na'budu WaIyyaaka Nasta'iin, Beirut: Dar Ehia Al-Thourath Al-Arabi, 1999

Ibnu Qayim Al-Jauziyah, Ighatsanu Lahfan min Mushahidis Syetan, Juz I, Kairo: tp 1999.

Imam al-Ghazali, Ihya 'Ulum ad-Din, terj. Ismail Ya'kub

Muhammad Husain, Agar Anak Mandiri, terj., Nashirul Haq, Bandung, Irsyad Baitus Salam, 2007.

Masnur Muslich, Pendidikan Karakter Menjawab Tantangan Krisis Multidimensional, Jakarta: Bumi Aksara, 2011

Yatimin Abdullah, Studi Akhlak dalam Perspektif al-Qur'an 